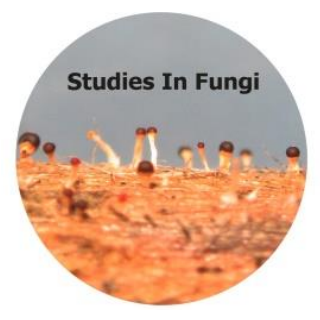

Studies in Fungi 3(1): 141-151 (2018) www.studiesinfungi.org ISSN 2465-4973 Article

Doi 10.5943/sif/3/1/16

Copyright $\odot$ Institute of Animal Science, Chinese Academy of Agricultural Sciences

\title{
Diaporthe collariana sp. nov., with prominent collarettes associated with Magnolia champaca fruits in Thailand
}

\author{
Perera RH ${ }^{1,2}$, Hyde KD ${ }^{2,3,4}$, Dissanayake AJ ${ }^{2,5}$, Jones EBG ${ }^{6}$, Liu JK ${ }^{1}$, Wei $\mathrm{D}^{3,7}$ \\ and Liu $\mathrm{ZY}^{1 *}$
}

\begin{abstract}
${ }^{1}$ Guizhou Key Laboratory of Agricultural Biotechnology, Guizhou Academy of Agricultural Sciences, Guiyang, Guizhou Province 550006, P.R. China.

${ }^{2}$ Center of Excellence in Fungal Research, Mae Fah Luang University, Chiang Rai 57100, Thailand.

${ }^{3}$ Key Laboratory for Plant Biodiversity and Biogeography of East Asia (KLPB), Kunming Institute of Botany, Chinese Academy of Science, Kunming 650201, Yunnan, China.

${ }^{4}$ World Agroforestry Centre, East and Central Asia, 132 Lanhei Road, Kunming 650201, P.R. China.

${ }^{5}$ Beijing Key Laboratory of Environmental Friendly Management on Fruit diseases and Pests in North China, Institute of Plant and Environment Protection, Beijing Academy of Agriculture and Forestry Sciences, Beijing 100097, People's Republic of China.

${ }^{6}$ Department of Botany and Microbiology, College of Science, King Saud University, P.O. Box: 2455, Riyadh, 1145, Saudi Arabia.

${ }^{7}$ Department of Entomology and Plant Pathology, Faculty of Agriculture, Chiang Mai University, Chiang Mai, 50200, Thailand.
\end{abstract}

Perera RH, Hyde KD, Dissanayake AJ, Jones EB, Liu JK, Wei D, Liu ZY 2018 - Diaporthe collariana sp. nov., with prominent collarettes associated with Magnolia champaca fruits in Thailand. Studies in Fungi 3(1), 141-151, Doi 10.5943/sif/3/1/16

\begin{abstract}
We are studying seed and fruit inhabiting fungi in Thailand and this paper introduces a new species, Diaporthe collariana, from Magnolia champaca fruits, collected in Chiang Rai Province. Molecular analysis of a combined ITS, TEF1, TUB and CAL sequence DNA and morphological data provide evidence to justify the new species. Diaporthe collariana is characterized by producing alpha and beta conidia, and conidiogenous cells with prominent, flared collarettes. The new species is compared with closely related species in the genus.
\end{abstract}

Key words - Diaporthaceae - morphology - new species - phylogeny - seed/fruit fungi

\section{Introduction}

Diaporthe species are plant pathogens, endophytes or saprobes, found on a wide range of hosts (Gomes et al. 2013, Gao et al. 2014, Dissanayake et al. 2017a, b, c). Previously species of this genus were considered as host-specific. However, as the same species can be found on more than one host, this is no longer valid (Rehner \& Uecker 1994, Gomes et al. 2013, Dissanayake et al. 2017b). Currently, 171 species of Diaporthe, have been described from various plant hosts worldwide and species rank supported with molecular data (Gomes et al. 2013, Dissanayake et al. 2017a, b, c, Gao et al. 2017). However, most old epithets of Diaporthe lack molecular data and some morphological descriptions lack informative data (Dayarathne et al. 2016, Gao et al. 2017, Index Fungorum 2017). Taxonomy of the genus relies largely on molecular phylogenies (Udayanga et al. 2012, Gomes et al. 2013), as few morphological characters can be used in species delimitation 
(Sutton 1980, Rehner \& Uecker 1994, Chi et al. 2007, Hyde et al. 2011, Dissanayake et al. 2017b, Gao et al. 2017). Currently, the pairwise dissimilarities of the internal transcribed spacer (ITS), translation elongation factor 1- $\alpha$ (TEF1), partial beta tubulin (TUB), histone H3 (HIS) and calmodulin (CAL) loci are useful when defining a new species (Udayanga et al. 2012, Gomes et al. 2013, Jeewon \& Hyde 2016, Dissanayake et al. 2017b, Gao 2017, Santos et al. 2017).

The leaf spot causing pathogenic species of Diaporthe (as Phomopsis micheliae Sankaran et al.) was identified from leaves of Magnolia champaca (=Michelia champaca) in India (Sankaran et al. 1987). It is characterized by simple septate conidiophores $(9-36 \times 1-1.5 \mu \mathrm{m})$, fusiform to ellipsoid alpha conidia, and filiform, hamate beta conidia $(16-34 \times 1.5 \mu \mathrm{m})$ (Sankaran et al. 1987). A homonym, P. micheliae C.Q. Chang et al., which was collected from living branches of Michelia alba in China, was introduced by Chang et al. (2005). However, this was not considered as a validly published species, since the name was already published by Sankaran et al. (1987) (Hawksworth \& David 1989 - Art. 53.1). Gao et al. (2017) treated Phomopsis micheliae as a synonymy of Diaporthe michelina (C.Q. Chang et al.) Y.H. Gao \& L. Cai.

In the current study, an undescribed species of Diaporthe is recognized by DNA sequence analysis, together with morphological characterization of asexual morphic structures.

\section{Materials \& methods}

\section{Sample collection, morphological examination and isolation}

Specimens were collected from Chiang Rai, Thailand during August 2017, and macroscopic and microscopic characters were observed in the laboratory. Fungal structures were observed using a Motic dissecting microscope (SMZ 168) and a Nikon ECLIPSE 80i compound microscope. Free hand sections of conidiomata were taken and mounted in water for microscopic study. Conidiophores, conidiogenous cells and conidia were mounted in Congo red for detailed observations. Photomicrography was carried out using a Canon 450D digital camera fitted to the microscope. Measurements were taken with the Tarosoft (R) Image Frame Work software. The images used for illustrating the fungi were processed with Adobe Photoshop CS5 v. 12.0 software (Adobe Systems, USA). Single conidial colonies were established as described in Chomnunti et al. (2014). Pure cultures were obtained on Potato Dextrose Agar (PDA) and incubated at room temperature of $28^{\circ} \mathrm{C}$. To induce sporulation, cultures were incubated at $28{ }^{\circ} \mathrm{C}$, in the dark. Conidiomata produced on PDA, were also illustrated following the above procedure.

Herbarium specimens were deposited in the Mae Fah Luang University (MFLU) herbarium, Chiang Rai, Thailand. Living cultures were deposited in the Culture Collection at Mae Fah Luang University (MFLUCC). Facesoffungi and Index Fungorum numbers were registered as explained in Jayasiri et al. (2015) and Index Fungorum (2017). Species are delineated based on DNA sequence data as in Jeewon \& Hyde (2016).

Table 1 Information on loci and PCR protocols used in the study.

\begin{tabular}{|c|c|c|}
\hline Locus & Primers (Reference) & PCR Conditions \\
\hline ITS & ITS5/ITS4 (White et al. 1990) & $\begin{array}{l}{ }^{\mathrm{a}} 94^{\circ} \mathrm{C}: 30 \mathrm{~s}, 48^{\circ} \mathrm{C}: 1 \mathrm{~min} . \\
72^{\circ} \mathrm{C}: 1 \mathrm{~min} .(37 \text { cycles })^{\mathrm{b}}\end{array}$ \\
\hline TEF1 & EF1-728F/ EF1-986R (Carbone \& Kohn 1999) & $\begin{array}{l}\text { a94 }{ }^{\circ} \mathrm{C}: 30 \mathrm{~s}, 55^{\circ} \mathrm{C}: 30 \mathrm{~s}, \\
72^{\circ} \mathrm{C}: 1.30 \mathrm{~min} .(35 \text { cycles })^{\mathrm{b}}\end{array}$ \\
\hline TUB & $\mathrm{Bt} 2 \mathrm{a} / \mathrm{Bt} 2 \mathrm{~b}$ (Glass \& Donaldson 1995) & $\begin{array}{l}{ }^{\mathrm{a}} 94{ }^{\circ} \mathrm{C}: 30 \mathrm{~s}, 55^{\circ} \mathrm{C}: 50 \mathrm{~s}, \\
72{ }^{\circ} \mathrm{C}: 1 \mathrm{~min} .(35 \text { cycles })^{\mathrm{b}}\end{array}$ \\
\hline CAL & CAL-228F/CAL-737R (Carbone \& Kohn 1999) & $\begin{array}{l}\text { a } 94{ }^{\circ} \mathrm{C}: 30 \mathrm{~s}, 58^{\circ} \mathrm{C}: 1 \mathrm{~min} . \\
72{ }^{\circ} \mathrm{C}: 1 \mathrm{~min} .(35 \text { cycles })^{\mathrm{b}}\end{array}$ \\
\hline
\end{tabular}

${ }^{\mathrm{a}}$ Initiation step of $94{ }^{\circ} \mathrm{C}: 3 \mathrm{~min}$

${ }^{b}$ Final elongation step of $72{ }^{\circ} \mathrm{C}: 7 \mathrm{~min}$. and final hold at $4{ }^{\circ} \mathrm{C}$ applied to all PCR thermal cycles 
Table 2 GenBank accession numbers of the isolates used in this study

\begin{tabular}{|c|c|c|c|c|c|}
\hline Species & $\begin{array}{l}\text { Culture } \\
\text { Collection No. }\end{array}$ & ITS & TEF1 & TUB & CAL \\
\hline $\begin{array}{l}\text { Diaporthe } \\
\text { alleghaniensis }\end{array}$ & CBS 495.72 & KC343007 & KC343733 & KC843228 & КС343249 \\
\hline D. alnea & CBS 146.46 & KC343008 & KC343734 & KC343976 & KC343977 \\
\hline D. alnea & CBS 159.47 & KC343009 & KC343735 & KC343977 & KC343251 \\
\hline D. apiculatum & LC3418 & KP267896 & KP267970 & KP293476 & - \\
\hline D. apiculatum & LC3187 & KP267866 & KP267940 & KP293446 & - \\
\hline D. betulae & CFCC 50469 & KT732950 & KT733016 & KT733020 & KT732997 \\
\hline D. betulae & CFCC 50470 & KT732951 & KT733017 & KT733021 & KT732998 \\
\hline D. bicincta & CBS 121004 & KC343134 & KC343860 & KC344102 & KC343376 \\
\hline D. biguttusis & CGMCC3.17081 & KF576282 & KF576257 & KF576306 & - \\
\hline D.biguttusis & CGMCC3.17082 & KF576283 & KF576258 & KF576307 & - \\
\hline D. celastrina & CBS 139.27 & KC343047 & KC343773 & KC344015 & KC343289 \\
\hline D. charlesworthii & BRIP54884m & KJ197288 & KJ197250 & KJ197268 & - \\
\hline D. citri & CBS 135422 & KC843311 & KC843071 & KC843187 & KC843157 \\
\hline D. citri & AR4469 & KC843321 & KC843081 & KC843197 & KC843167 \\
\hline D. citrichinensis & ZJUD34 & JQ954648 & JQ954666 & KJ490396 & КC357494 \\
\hline D. citrichinensis & ZJUD85 & KJ490620 & KJ490499 & KJ490441 & - \\
\hline D. collariana & $\begin{array}{l}\text { MFLUCC 17- } \\
2636\end{array}$ & MG806115 & MG783040 & MG783041 & MG783042 \\
\hline D. cotoneastri & CBS 439.82 & FJ889450 & GQ250341 & JX275437 & JX197429 \\
\hline D. discoidispora & ZJUD89 & KJ490622 & KJ490501 & KJ490443 & - \\
\hline D. ellipicola & CGMCC3.17084 & KF576270 & KF576245 & KF576291 & - \\
\hline D. ellipicola & CGMCC3.17085 & KF576271 & KF576246 & KF576295 & - \\
\hline D. eres & AR5193 & KJ210529 & $\mathrm{KJ} 210550$ & KJ420799 & KJ434999 \\
\hline D. eres & $\begin{array}{l}\text { LCM11401a= } \\
\text { CBS } 138598\end{array}$ & KJ210521 & KJ210545 & KJ420787 & KJ435027 \\
\hline D. eres & DLR12a & $\mathrm{KJ} 210518$ & KJ210542 & KJ420783 & KJ434996 \\
\hline D. fukushii & MAFF 625029 & JQ807469 & JQ807418 & - & - \\
\hline D. gardeniae & CBS 288.56 & KJ197289 & KJ197252 & KJ197270 & - \\
\hline D. helicis & AR5211 & KJ210538 & KJ210559 & KJ420828 & KJ435043 \\
\hline D. longicicola & $\begin{array}{l}\text { CGMCC } \\
3.17089\end{array}$ & KF576267 & KF576242 & KF576291 & - \\
\hline D. longicicola & $\begin{array}{l}\text { CGMCC } \\
3.17090\end{array}$ & KF576268 & KF576243 & KF576292 & - \\
\hline D. lonicerae & $\begin{array}{l}\text { MFLUCC 17- } \\
0963\end{array}$ & KY964198 & KY964154 & KY964082 & KY964122 \\
\hline D. mahothocarpus & CGMCC3 15181 & KC153096 & KC153087 & - & - \\
\hline D. mahothocarpus & CGMCC3 15182 & KC153097 & KC153088 & - & - \\
\hline D. maritima & $\begin{array}{l}\text { DAOMC } \\
250563\end{array}$ & KU552027 & KU552022 & KU574616 & - \\
\hline D. momicola & $\begin{array}{l}\text { MFLUCC 16- } \\
0113\end{array}$ & KU557563 & KU557631 & KU557587 & KU557611 \\
\hline D. neilliae & CBS 144.27 & KC343144 & KC343870 & KC344112 & КC343386 \\
\hline D. nobilis & CBS 587.79 & KC343153 & КC343879 & KC344121 & КC343395 \\
\hline D. oraccinii & LC3166 & KP267863 & KP267937 & KP293443 & - \\
\hline
\end{tabular}


Table 2 Continued.

\begin{tabular}{llllll}
\hline Species & $\begin{array}{l}\text { Culture } \\
\text { Collection No. }\end{array}$ & ITS & TEF1 & TUB & CAL \\
\hline D. penetriteum & LC3215 & KP267879 & KP267953 & KP293459 & - \\
D. penetriteum & LC3353 & KP714505 & KP714517 & KP714529 & - \\
D. penetriteum & LC3394 & KP267893 & KP267967 & KP293473 & - \\
D. phragmitis & CBS 138897 & KP004445 & - & KP004507 & - \\
D. pulla & CBS 338.89 & KC343152 & KC343878 & KC344120 & KC343394 \\
D. sennicola & CFCC 51634 & KY203722 & KY228883 & KY228889 & KY228873 \\
D. sennicola & CFCC 51635 & KY203723 & KY228884 & KY228890 & KY228874 \\
D. subclavata & ZJUD83 & KJ490618 & KJ490497 & KJ490439 & - \\
D. subclavata & ZJUD95 & KJ490630 & KJ490509 & KJ490451 & - \\
D. vaccinii & CBS 122116 & KC343227 & KC343953 & KC344195 & KC343469 \\
D. vaccinii & CBS 160.32 & AF317578 & GQ250326 & JX270436 & KC343470 \\
D. virgiliae & CMW 40748 & KP247566 & - & KP247575 & - \\
Diaporthella corylina & CBS 121124 & KC343004 & KC343730 & KC343972 & KC343246 \\
\hline
\end{tabular}

\section{DNA isolation, amplification and analysis}

Genomic DNA was extracted from fungal colonies growing on PDA, using the Biospin Fungus Genomic DNA Extraction Kit-BSC14S1 (BioFlux, P.R. China), following the manufacturer's protocol. Gene regions of ITS, TEF1, TUB and CAL were amplified using the primer pairs and PCR protocols listed in Table 1. Amplifications were performed in $25 \mu \mathrm{l}$ of PCR mixtures containing $9.5 \mu \mathrm{dddH} 2 \mathrm{O}, 12.5 \mu \mathrm{l} 2 \times$ PCR Master Mix, $1 \mu \mathrm{l}$ of DNA template and $1 \mu \mathrm{l}$ of each primer $(10 \mu \mathrm{M})$. The PCR products were visualized by staining with ethidium bromide after $1 \%$ agarose gel electrophoresis. Purification and sequencing of PCR products were done by Shanghai Sangon Biological Engineering Technology \& Services Co., China. To ensure the integrity of the sequences, both directions of the PCR products were sequenced using the same primer pairs as used in PCR amplification. A consensus sequence for each gene region was assembled in ContigExpress (Vector NTI Suite 6.0).

The sequences generated in this study were supplemented with additional sequences obtained from GenBank (Table 2), selected based on recent publications (Gomes et al. 2013, Huang et al. 2015, Gao et al. 2016, 2017, Dissanayake et al. 2017a, b, c). The sequence data were aligned online with the MAFFT v. 7 server (http://mafft.cbrc.jp/ alignment/server/) and manually adjusted using MEGA6 v. 6.0 where necessary (Tamura et al. 2011). Phylogenetic analyses were based on Bayesian inference (BI), maximum likelihood (ML) and maximum parsimony (MP) methods.

MP analysis was carried out using PAUP (Phylogenetic Analysis Using Parsimony) v.4.0b10 (Swofford 2002). The trees were inferred using the heuristic search option with 1000 random taxa additions and tree bisection and reconnection (TBR) as the branch-swapping algorithm. Ambiguously aligned regions were excluded from all analyses and gaps were treated as missing data. Maxtrees were setup to 5000, branches of zero length were collapsed and all multiple, equally parsimonious trees were saved. Stability of the clade were assessed using a bootstrap (BT) analysis with 1000 replicates, each with 100 replicates of random stepwise addition of taxa (Hillis \& Bull 1993). Tree length [TL], consistency index [CI], retention index [RI], rescaled consistency index [RC], homoplasy index [HI], and log likelihood [-ln L] (HKY model) values were calculated. The robustness of the equally most parsimonious trees was evaluated by 1000 bootstrap replications (Felsenstein 1985) resulting from a maximum parsimony analysis, each with 10 replicates of random stepwise addition of taxa. The Kishino-Hasegawa tests (Kishino \& Hasegawa 1989) were performed to determine whether the trees inferred under different optimality criteria were significantly different. ML analysis was performed using RAxML GUI v. 1.3 (Silvestro \& Michalak 2011). The optimal ML tree search was conducted with 1000 separate runs, using the 
default algorithm of the program from a random starting tree for each run. The final tree was selected among suboptimal trees from each run by comparing likelihood scores with the GTRGAMMA nucleotide substitution model. MrBayes v. v. 3.2.0 was used to generate the phylogenetic trees under optimal criteria per data partition (Ronquist \& Huelsenbeck 2003). Bayesian analysis was performed using MrBayes v. 3.2.0. The best-fit evolutionary models for phylogenetic analyses were selected separately for ITS, TEF1, TUB and CAL gene regions using MrModeltest v. 2.2 (Nylander 2004). The GTR+I+G model was selected for ITS and TUB, while GTR+G was selected for TEF1 and CAL, separately, and incorporated into the analysis. Two parallel analyses of each consisting of six Markov Chain Monte Carlo (MCMC) chains, run from random trees for 6000000 generations were sampled every 100 generations resulting in 20000 total trees. The first 10000 trees, representing the burn in phase of the analyses were discarded from each run. The remaining trees were used to calculate posterior probabilities (PP) in the majority rule consensus tree. Trees were viewed by FigTree v1.4 (http://tree.bio.ed.ac.uk/software/figtree/) and edited using Microsoft PowerPoint 2010.

\section{Results}

\section{Phylogenetic analyses}

Single gene analyses of ITS, TEF1 and TUB were carried out for all the available sequences of Diaporthe species to compare the topology of the trees and clade stability (data not shown). Based on those analyses and blast results, 48 isolates were selected (including the outgroup taxon) for the combined gene analysis of ITS, TEF1, TUB and CAL (Table 2). The aligned dataset comprised 1766 characters including gaps (ITS: 1-468, TEF1: 469-922, TUB: 923-1283 and CAL: 1284-1766), of which 970 were constant, 393 parsimony-informative and 403 parsimonyuninformative. The parsimony analysis resulted in 8 equally most parsimonious trees (TL $=1628$ steps, $\mathrm{CI}=0.641, \mathrm{RI}=0.731, \mathrm{RC}=0.469, \mathrm{HI}=0.359$ ). Bayesian inference and maximum parsimony analyses of the combined data set yielded trees with similar topologies to maximum likelihood tree. The best scoring RAxML tree with a final likelihood value of -10272.773331 is presented (Fig. 1). The matrix comprised 732 distinct alignment patterns, with $19.13 \%$ of undetermined characters or gaps. Estimated base frequencies were as follows; $\mathrm{A}=0.220005, \mathrm{C}=$ $0.316011, \mathrm{G}=0.233364, \mathrm{~T}=0.230620$; substitution rates $\mathrm{AC}=1.337142, \mathrm{AG}=3.640863, \mathrm{AT}=$ $1.113669, \mathrm{CG}=1.137669, \mathrm{CT}=5.044583, \mathrm{GT}=1.000000$; gamma distribution shape parameter $\alpha$ $=0.501532$.

In the phylogenetic analysis, our new isolate Diaporthe collariana clustered with $D$. subclavata isolate ZJUD83, with a high statistical support (100\% MLBT, 100\% MPBT, 1.00 PP). The ex-type strain of $D$. subclavata also shows a close relationship to D. collariana.

\section{Taxonomy}

Diaporthe collariana R. H. Perera \& K. D. Hyde sp. nov.

Figs 2, 3

Indexfungorum: IF554061; Facesoffungi: FoF03909

Etymology - Named after its prominently flared collarettes.

Saprobic on Magnolia champaca. Asexual morph from the natural substrate - Conidiomata 190$325 \mu \mathrm{m}$ wide, 310-550 $\mu \mathrm{m}$ high, pycnidial, eustromatic, subepidermal, semi immersed, scattered, globose to ampullifom or irregular, black, outer surface smooth, convoluted to unilocular, singly ostiolate, with prominent necks $150-290 \mu \mathrm{m}$ long. Peridium 18-25 $\mu \mathrm{m}$ thick, 5-9 cells thick, consisting brown to hyaline cells of textura angularis. Conidial mass globose or sometimes exuding in cirrhi, white to pale-yellow. Alpha conidiophores $12.1-20.6 \times 2.4-3.2 \mu \mathrm{m}(\bar{x}=16.6 \times$ $2.8 \mu \mathrm{m})$, densely aggregated, ampulliform to subcylindrical, rarely septate and branched, hyaline. Alpha conidiogenous cells $10-17 \times 1.3-2.4 \mu \mathrm{m}(\bar{x}=13.7 \times 1.8 \mu \mathrm{m})$ subcylindrical, tapering towards the apex, hyaline, with visible periclinal thickening, collarette prominent, up to $6 \mu \mathrm{m}$ long, $5.7 \mu \mathrm{m}$ wide. Alpha conidia $4.2-6.2 \times 1.5-2 \mu \mathrm{m}(\bar{x}=5.2 \times 1.7 \mu \mathrm{m})$, less common than beta 
conidia, oblong to ellipsoidal, apex bluntly rounded, base obtuse to subtruncate, aseptate, straight, guttulate, hyaline, smooth-walled. Beta conidiophores $10.3-19 \times 1.4-3.5 \mu \mathrm{m}(\bar{x}=14.6 \times 2.6 \mu \mathrm{m})$, densely aggregated, subcylindrical, filiform or obconical, branched and septate, hyaline. Beta conidiogenous cells $3.8-14 \times 1.4-2.2 \mu \mathrm{m}(\bar{x}=7.9 \times 1.8 \mu \mathrm{m})$ subcylindrical, tapering towards the apex, hyaline, with visible periclinal thickening, collarette prominent, up to $6.6 \mu \mathrm{m}$ long, $5.7 \mu \mathrm{m}$ wide. Beta conidia $22-31.3 \times 0.8-1.6 \mu \mathrm{m}(\bar{x}=27.7-1.2 \mu \mathrm{m})$, commonly found, straight, curved or hamate, hyaline, smooth-walled. Gamma conidia not observed. Asexual morph on PDA Conidiomata 600-636 $\mu \mathrm{m}$ wide, 1045-1170 $\mu \mathrm{m}$ high, pycnidial, aggregated in small groups, globose to ampullifom, unilocular, black, with a prominent neck. Peridium consisting brown cells of textura angularis. Conidial mass globose or sometimes exuding in cirrhi, white to pale-yellow. Alpha conidiophores $12-20 \times 2.4-3.2 \mu \mathrm{m}(\bar{x}=17.2 \times 2.8 \mu \mathrm{m})$, densely aggregated, ampulliform to subcylindrical, rarely septate and branched, hyaline. Alpha conidiogenous cells $11.1-17 \times 1.3-$ $2.4 \mu \mathrm{m}(\bar{x}=14.4 \times 1.8 \mu \mathrm{m})$ subcylindrical, tapering towards the apex, hyaline, with visible periclinal thickening, collarette prominent, up to $3.5 \mu \mathrm{m}$ long, $3.2 \mu \mathrm{m}$ wide. Alpha conidia 4.7-5.6 $\times 1.7-2.2 \mu \mathrm{m}(\bar{x}=5.2 \times 1.9 \mu \mathrm{m})$, less common than beta conidia, oblong to ellipsoidal, apex bluntly rounded, base obtuse to subtruncate, aseptate, straight, bi-guttulate, hyaline, smooth-walled. Beta conidiophores 13.2-20.8 $\times 1.3-4.1 \mu \mathrm{m}(\bar{x}=17.4 \times 3.6 \mu \mathrm{m})$, densely aggregated, subcylindrical, filiform or obconical, branched and septate, hyaline. Beta conidiogenous cells 8.8 $13.4 \times 1.7-2.3 \mu \mathrm{m}(\bar{x}=10.8 \times 2.1 \mu \mathrm{m})$ subcylindrical, tapering towards the apex, hyaline, with visible periclinal thickening, collarette prominent, up to $3.5 \mu \mathrm{m}$ long, $3.2 \mu \mathrm{m}$ wide. Beta conidia 22-31.7 $\times 1.1-1.6 \mu \mathrm{m}(\bar{x}=28.8-1.3 \mu \mathrm{m})$, commonly found, straight, curved or hamate, hyaline, smooth-walled. Gamma conidia not observed. Sexual morph - Undetermined.

Culture characters - Conidia germinating on WA (Water Agar) within $12 \mathrm{~h}$ and germ tubes produced from one end. Colonies growing on PDA, reaching $6 \mathrm{~cm}$ in 7 days at $25^{\circ} \mathrm{C}$, flat, initially white, aerial mycelium forming concentric rings with cottony texture, white to olivaceous, reverse zonate with white and ash-brown rings. Sporulate on PDA after 2 months incubation period in dark, at $25^{\circ} \mathrm{C}$.

Material examined - THAILAND, Chiang Rai, Mae Fah Luang University premises, on dried fruits and pedicels of Magnolia champaca (L.) Baill. ex Pierre (Magnoliaceae), 17 August 2017, S. Boonmee, Fruit 3 (MFLU 17-2770, holotype), MFLU 17-2845 dried culture on PDA, ex-type living culture, MFLUCC 17-2636. (GenBank: LSU: MG806114)

Notes - Our new fungus Diaporthe collariana nested in between two D. subclavata strains and was more related to strain ZJUD83, which was collected from a fruit of Citrus maxima cv. Shatianyou in China, with very good support (Fig. 1). Nucleotide comparison reveals 5 (1.3\%) differences in the ITS region, $10(2.1 \%)$ in the TEF1 region, $11(1.4 \%)$ in the TUB region. The extype strain of $D$. subclavata (ZJUD95) is the next phylogenetically closest isolate to Diaporthe collariana (Fig. 1). Nucleotide comparison reveals 15 (3.8\%) were distinct in the ITS region, 46 $(9.7 \%)$ in the TEF1 region, $10(1.2 \%)$ in the TUB region. CAL region is not available for $D$. subclavata strains in GenBank (Huang et al. 2015). Diaporthe collariana differs from D. subclavata in the presence of beta conidia. Furthermore, D. collariana produces prominent collarettes while collarets are absent in D. subclavata. On PDA, D. collariana produces smaller alpha conidia, which are oblong to ellipsoidal $(4.7-5.6 \times 1.7-2.2 \mu \mathrm{m})$, while $D$. subclavata produces fusiform to clavate conidia $(5.5-7.2 \times 2.2-2.9 \mu \mathrm{m})$ (Huang et al. 2015). The placement of $D$. collariana in between two isolates of $D$. subclavata is rather intriguing. However, by comparing available gene sequences of D. subclavata strains, we confirm that ZJUD83 is different from its extype ZJUD95. This is further discussed below.

Diaporthe micheliae, is another species which lacks molecular data in the GenBank, and was also isolated from the same host as D. collariana (Sankaran et al. 1987). However, D. collariana can be distinguished from $D$. micheliae by having prominent collarettes which are absent in $D$. micheliae, branched conidiophores (vs. simple conidiophores), and smaller alpha conidia (4.7-5.6 $\times$ 1.7-2.2 vs. 4.6-8.2(-11.5) × 2-2.8 $\mu \mathrm{m})($ Sankaran et al. 1987). 


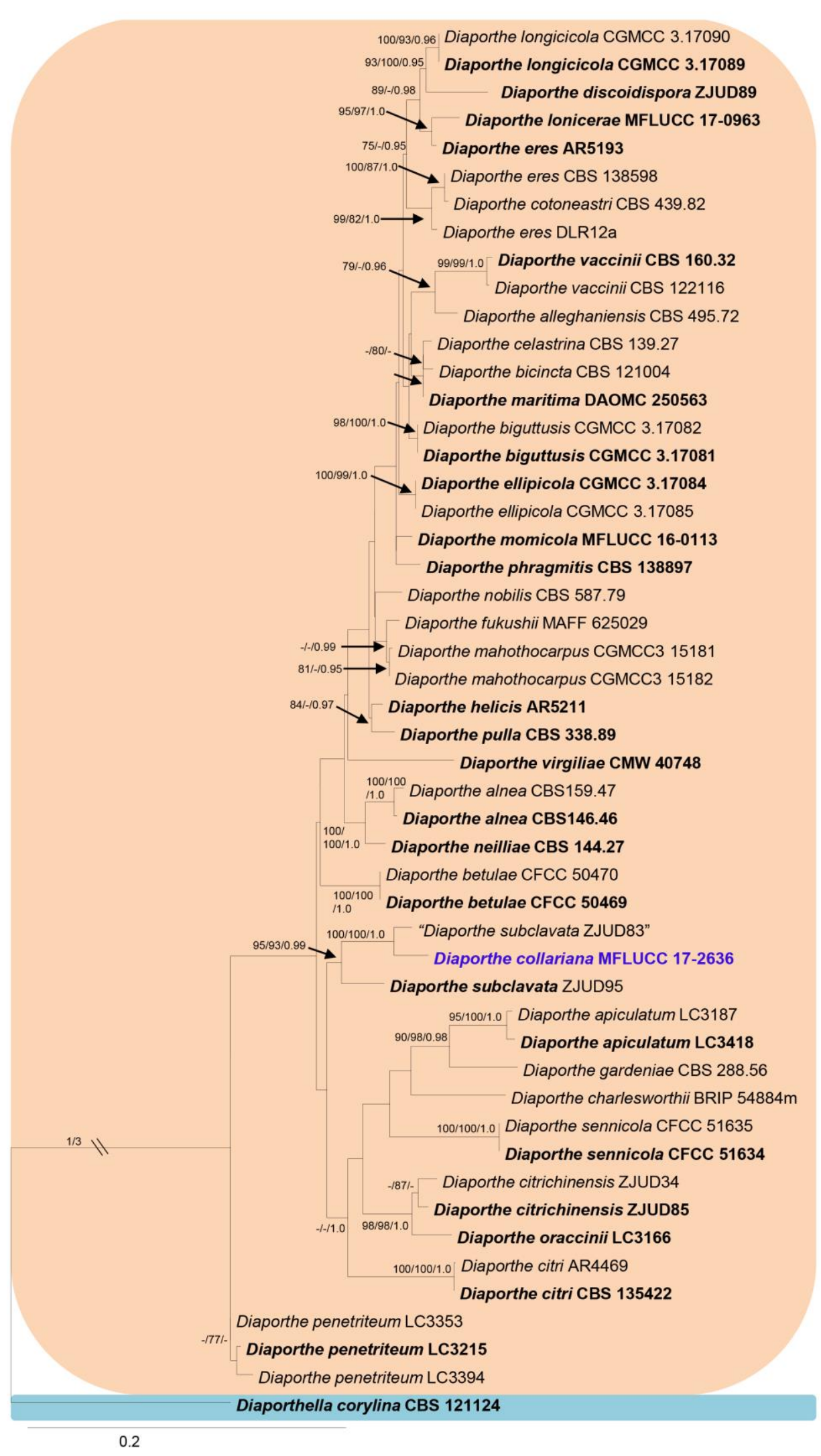

Fig. 1 - Phylogram generated from maximum likelihood analysis based on combined ITS, TEF1, TUB, and CAL sequence data of selected Diaporthe species. Values near the nodes indicate maximum likelihood and maximum parsimony bootstrap $\geq 75 \%$, (MP/ML). Values at the third positions, respectively, represent posterior probabilities ( $\mathrm{PP} \geq 0.95$ ) from Bayesian inference analysis. The ex-type strains are in bold and new isolates in blue. The scale bar indicates 0.2 nucleotide changes per site. The tree is rooted to Diaporthella corylina (CBS 121124). 


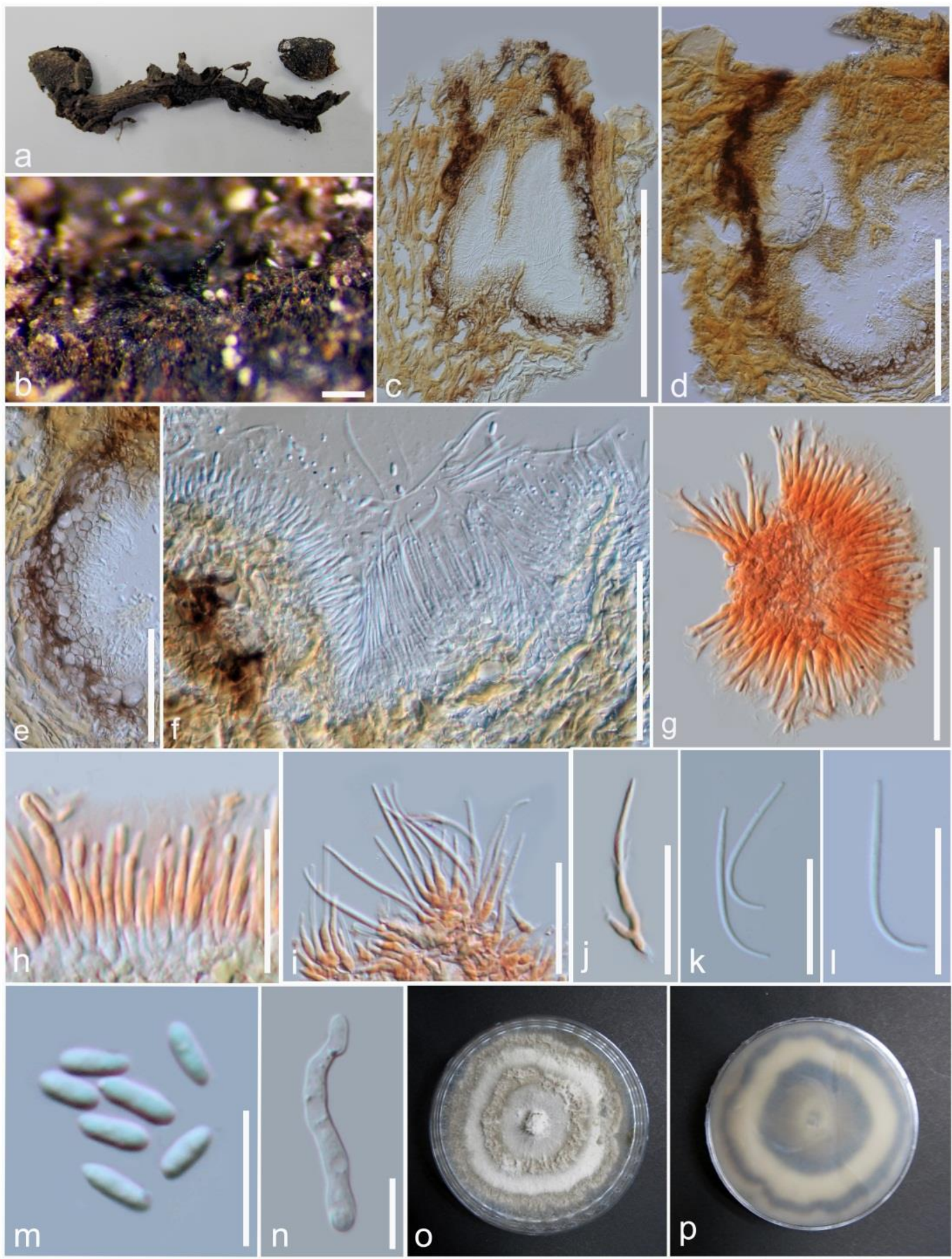

Fig. 2 - Diaporthe collariana (MFLU 17-2770, holotype). a Herbarium material. b Conidioma on host substrate. c, d Section through conidiomata. e Peridium. f Alpha and beta conidia inside the same conidiomata. g, h Conidiophores with alpha conidia (in Congo red). i, j Conidiophores with beta conidia (in Congo red). $\mathrm{k}, 1$ Beta conidia. $\mathrm{m}$ Alpha conidia. $\mathrm{n}$ Germinating conidium. $\mathrm{o}, \mathrm{p}$ Colony on PDA. Scale bars: $\mathrm{b}, \mathrm{c}=200 \mu \mathrm{m}, \mathrm{d}=50 \mu \mathrm{m}, \mathrm{e}-\mathrm{g}=50 \mu \mathrm{m}, \mathrm{h}-\mathrm{l}=20 \mu \mathrm{m}, \mathrm{m}, \mathrm{n}=10$ $\mu \mathrm{m}$. 


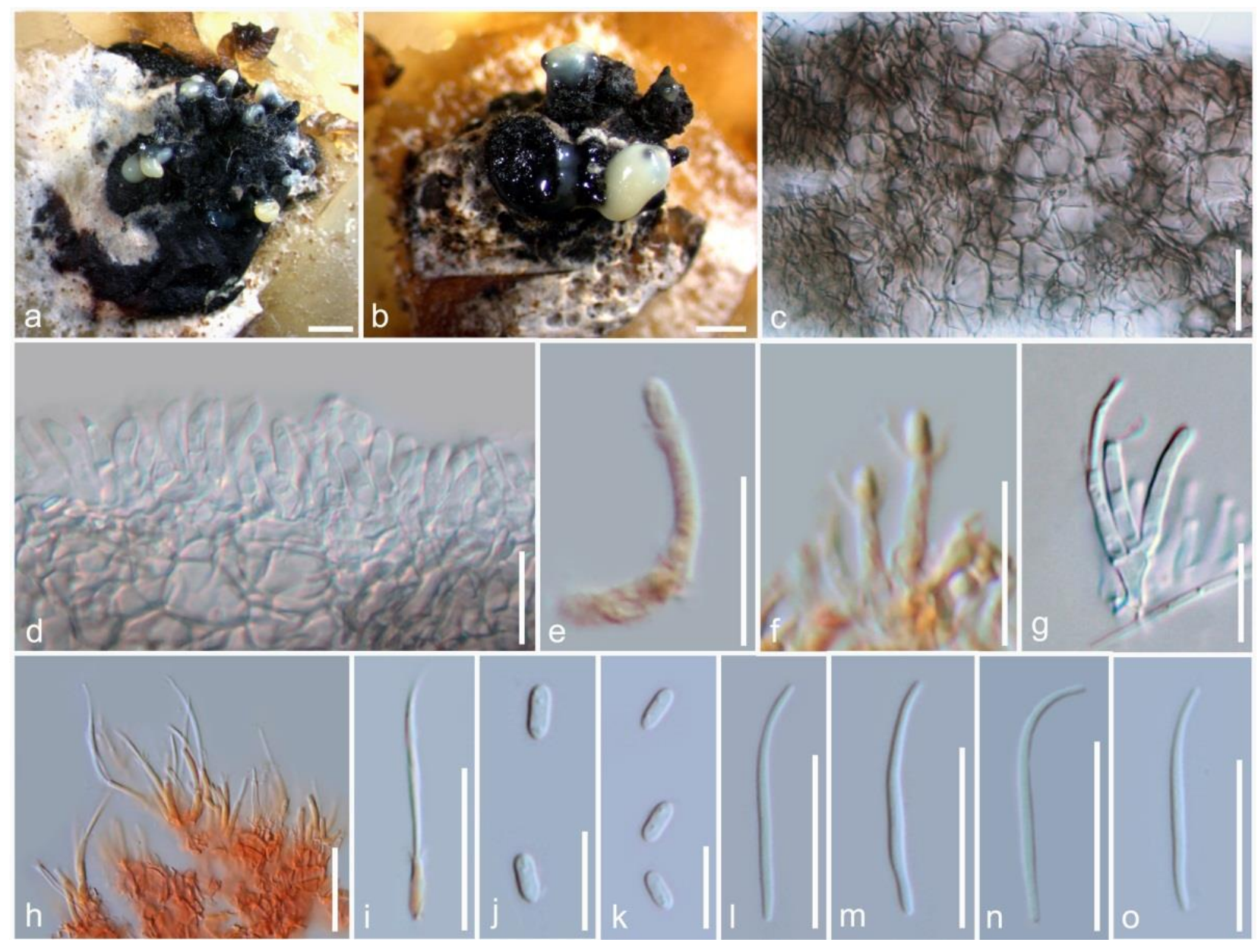

Fig. 3 - Diaporthe collariana (MFLU 17-2845) a, b Conidiomata on PDA. c Peridium in surface view. d Developing conidiophores with conidiogenous cells. e, f Conidiogenous cells with alpha conidia (in Congo red). g-i Conidiophores with beta conidia (h, i. in Congo red). j, k Alpha conidia. l-o Beta conidia. Scale bars: $\mathrm{a}, \mathrm{b}=1 \mathrm{~mm}, \mathrm{c}=20 \mu \mathrm{m}, \mathrm{d}-\mathrm{f}=10 \mu \mathrm{m}, \mathrm{g}=10 \mu \mathrm{m}, \mathrm{h}, \mathrm{i}=20 \mu \mathrm{m}$, $\mathrm{j}, \mathrm{k}=10 \mu \mathrm{m}, \mathrm{l}-\mathrm{O}=20 \mu \mathrm{m}$.

\section{Discussion}

Magnolia champaca is an evergreen or semi-deciduous plant native to India, and exotic to many other Asian countries including Thailand (Orwa et al. 2009). Dried fruits of M. champaca were collected in rainy season, under trees in Mae Fah Luang University garden and examined for fungi. The garden floor is free of pesticides and herbicides. Here we illustrate the morphology of the fungus on natural substrates and in vitro on PDA. Conidiomata on PDA are larger and produce longer necks than the ones on the natural host (Figs 2, 3). However, other characters such as, conidiophores, conidiogenous cells and conidia are similar in both culture and natural substrates.

There are two strains of $D$. subclavata available in the GenBank including the ex-type. However, ex-type ZJUD95 and the putative strain of D. subclavata (ZJUD83) do not cluster together in our analysis (Fig. 1). Isolate ZJUD83 was collected from fruit of C. maxima cv. Shatianyou in Guangdong province, China, while the ex-type stain of D. subclavata (ZJUD95) was collected from C. unshiu in Fujian Province, China (Huang et al. 2015). Nucleotide comparison between D. subclavata isolates ZJUD95 and ZJUD83 reveals $14(3.5 \%)$ were distinct in the ITS region, $52(10.9 \%)$ in the TEF1 region, $9(1.1 \%)$ in the TUB region and $31(6.6 \%)$ in the HIS region, which means ZJUD83 isolate is probably a different species. However, no morphological descriptions are available for ZJUD83 for any comparison with holotype of D. subclavata (Huang et al. 2015). Given that Diaporthe species are of economic importance, it would be wise to relook into the herbarium material of ZJUD83, recollect the sample and perform phylogenetic analyses on same to clarify its taxonomy. 


\section{Acknowledgements}

The Research of Featured Microbial Resources and Diversity Investigation in Southwest Karst area (Project No. 2014FY120100) is thanked for financial support. Kevin D. Hyde thanks the Chinese Academy of Sciences, project number 2013T2S0030, for the award of a Visiting Professorship for Senior International Scientists at Kunming Institute of Botany. The authors extend their appreciation to the International Scientific Partnership Program ISPP at King Saud University for funding this research work through ISPP\#0089.

\section{References}

Carbone I, Kohn LM. 1999 - A method for designing primer sets for speciation studies in filamentous ascomycetes. Mycologia 91, 553-556.

Chang CQ, Cheng YH, Xiang MM, Jiang ZD, Chi PK. 2005 - New species of Phomopsis on woody plants in Fujian province. Mycosystema 24, 6-11.

Chomnunti P, Hongsanan S, Aguirre-Hudson B, Tian Q et al. 2014 - The sooty moulds. Fungal Diversity 66, 1-36.

Chi P, Jiang Z, Xiang M. 2007 - Flora Fungorum Sinicorum 34: Phomopsis. Science, Beijing.

Dayarathne MC, Boonmee S, Braun U, Crous PW et al. 2016 - Taxonomic utility of old names in current fungal classification and nomenclature: Conflicts, confusion and clarifications. Mycosphere 7, 1622-1648.

Dissanayake AJ, Camporesi E, Hyde KD, Zhang Wei, Yan JY, Li XH. 2017a - Molecular phylogenetic analysis reveals seven new Diaporthe species from Italy. Mycosphere 8, 853877.

Dissanayake AJ, Phillips AJL, Hyde KD, Yan JY, Li XH. 2017b - The current status of species in Diaporthe. Mycosphere 8, 1106-1156.

Dissanayake AJ, Zhang W, Liu M, Hyde KD et al. 2017c - Diaporthe species associated with peach tree dieback in Hubei, China. Mycosphere 8, 533-549.

Felsenstein J. 1985 - Confidence limits on phylogenies: an approach using the bootstrap. Evolution 39, 783-791.

Gao Y, Liu F, Cai L. 2016 - Unravelling Diaporthe species associated with Camellia. Systematics and Biodiversity 14, 102-117.

Gao Y, Liu F, Duan W, Crous PW, Cai L. 2017 - Diaporthe is paraphyletic. IMA Fungus 8, 153187.

Gao YH, Su YY, Sun W, Cai L. 2014 - Diaporthe species occurring on Lithocarpus glabra in China, with descriptions of five new species. Fungal Biology 119, 295-309.

Glass NL, Donaldson GC. 1995 - Development of primer sets designed for use with the PCR to amplify conserved genes from filamentous ascomycetes. Applied and Environmental Microbiology 61, 1323-1330.

Gomes RR, Glienke C, Videira SI, Lombard L, Groenewald JZ, Crous PW. 2013 - Diaporthe: a genus of endophytic, saprobic and plant pathogenic fungi. Persoonia: Molecular Phylogeny and Evolution of Fungi. 31, 1-41.

Hawksworth DL, David JC. 1989 - Family names. Index of Fungi Supplement - C.A.B. International. Wallingford, U.K.

Hillis DM, Bull JJ. 1993 - An empirical test of bootstrapping as a method for assessing confidence in phylogenetic analysis. Systematic Biology 42, 182-192.

Huang F, Udayanga D, Wang X, Hou X et al. 2015 - Endophytic Diaporthe associated with Citrus: A phylogenetic reassessment with seven new species from China. Fungal Biology 119, 331347.

Ronquist F, Huelsenbeck JP. 2003 - MrBayes 3: Bayesian phylogenetic inference under mixed models Bioinformatics 19, 1572-1574.

Hyde KD, McKenzie EHC, KoKo TW. 2011 - Towards incorporating anamorphic fungi in a natural classification-checklist and notes for 2010. Mycosphere 2, 1-88. 
Index Fungorum. 2017 - www.indexfungorum.org.

Jayasiri SC, Hyde KD, Ariyawansa HA, Bhat J et al. 2015 - The Faces of Fungi database: fungal names linked with morphology, phylogeny and human impacts. Fungal Diversity 74, 3-18.

Jeewon R, Hyde KD. 2016 - Establishing species boundaries and new taxa among fungi: recommendations to resolve taxonomic ambiguities. Mycosphere 7, 1669-1677.

Kishino H, Hasegawa M. 1989 - Evaluation of the maximum likelihood estimate of the evolutionary tree topologies from DNA sequence data. Journal of Molecular Evolution 29, $170-179$.

Nylander JAA. 2004 - MrModeltest v2. Program distributed by the author Evolutionary Biology Centre, Uppsala University, Sweden.

Orwa C, Mutua A, Kindt R, Jamnadass R, Anthony S. 2009 - Agroforestree Database:a tree reference and selection guide version 4.0 (http://www.worldagroforestry.org/treedb/AFTPDFS/Michelia_champaca.PDF)

Rehner SA, Uecker FA. 1994 - Nuclear ribosomal internal transcribed spacer phylogeny and host diversity in the coelomycete Phomopsis. Canadian Journal of Botany 72, 1666-1674.

Sankaran KV, Florence EJM, Sharma JK. 1987 - Two new species of Phomopsis from India. Transactions of the British Mycological Society 89, 404-407.

Santos L, Alves A, Alves R. 2017 - Evaluating multi-locus phylogenies for species boundaries determination in the genus Diaporthe. PeerJ 5, e3120.

Silvestro D, Michalak I. 2011 - raxmlGUI: a graphical front-end for RAxML. Organisms. Diversity and Evolution 12, 335-337.

Swofford DL. 2002 - PAUP*: phylogenetic analysis using parsimony, version 4.0 b10. Sinauer Associates, Sunderland.

Sutton BC. 1980 - The coelomycetes. Fungi imperfecti with pycnidia, acervuli and stromata. Commonwealth Mycological Institute, Kew, Surrey, England.

Tamura K, Peterson D, Peterson N, Stecher G, Nei M, Kumar S. 2011 - MEGA5: molecular evolutionary genetics analysis using maximum likelihood, evolutionary distance, and maximum parsimony methods. Molecular Biology and Evolution 28, 2731-2739.

Udayanga D, Liu XZ, Crous PW, McKenzie EH, Chukeatirote E, Hyde KD. 2012 - A multi-locus phylogenetic evaluation of Diaporthe (Phomopsis). Fungal Diversity 56, 157-171.

White TJ, Bruns T, Lee S, Taylor J. 1990 - Amplification and direct sequencing of fungal ribosomal RNA genes for phylogenetics. In: Innis MA, Gelfand DH, Sninsky JJ, White TJ (eds), PCR Protocols: a guide to methods and applications. Academic Press, New York, pp. $315-322$. 